\title{
Güzellik tüketimi estetiği olarak Winx çizgi film serisi ve zihin altı mesajları
}

\section{Özlem Küçük ${ }^{*} \odot$}

'Öğr. Gör. Dr. | Kocaeli Üniversitesi, Turizm Fakültesi, Turizm İşletmeciliği Bölümü, Kocaeli - Türkiye

* Sorumlu Yazar / Corresponding Author Özlem Küçük Kocaeli Üniversitesi

Turizm Fakültesi

Turizm Iş̧letmeciliği Bölümü

41080 Kartepe, Kocaeli / Türkiye

E-posta: ozlem.kucuk@kocaeli.edu.tr

Alındı/Received: 5 Şubat / February 2021 | Düzeltildi/Revised: 10 Haziran / June 2021 | Kabul/Accepted: 17 Haziran / June 2021 |Yayımlandı/Published: 28 Haziran / June 2021

\section{Öz}

İtalyan Iginio Straffi tarafindan üretilen Winx Club film serisi, cadılar, periler ve doğaüstü yaratıkların bir arada yaşadığı fantastik bir evreni konu almaktadır. Straffi, animasyon filminin tasarımında Japon mangasını (çizgi roman) ve Batı öğelerini beraber kullanmıştır. Böylece, doğa üstü güçleri olan peri kahramanların fiziksel görünümleri, Beyonce, Jennifer Lopez ve Kim Kardashian'a benzetilmiştir. İletişim teknolojilerinin yayılımı ve popülaritesinin arttığı günümüzde, eskiden var olan değerler ve toplumsal bağların dışında yeni bir tüketim kültürün ortaya çıktığını görmekteyiz. Straffi, filmin beklentinin üzerinde başarısı sonrası, Viacom (ABD'li medya şirketi) ile ortaklık kurmuştur. Birlikteliğin ardından yayımlanan yeni bölümlerde, daha abartılı dış görünüm ve lüks tüketim ön plandadır. Bir şeyi yada birini güzel yapan şey, ister kişinin, ister nesnenin bir özelliği olsun, daha ziyade bakanın nazarındadır. Tam olarak neyin güzel olduğu hususunda bir fikir birliği olup olmadığı antik çağlardan beri düşünürleri meşgul eden hususlardan biridir. Ancak, Winx perileri tek tip ve yapay güzelliğin büyülü evreninde beden ve kimlik üzerinde yerel kültürel etkilerden bağımsız, lüks tüketimi ve kozmetik cerrahiyi özendirir imgeleri barındırır içinde. Nitekim gençler, erişkinler ve çocuklar için yeni nesil tüketim kültürü ve pazar öğelerini içermektedir. Winx kanatları, dergileri, kitapları, bebekleri, giysileri, ayakkabıları, kırtasiye ürünleri, makyaj malzemeleri şeklinde envai tür, tüketim ürünü olarak karșımıza çıkmaktadır. Bu çalışmada, Winx Club animasyon filminin fiziksel görünüş ve yapay güzellik algısıyla Schiller’in estetik güzellik algısı karşılaştırılırken, klasik liberalizmin bir yansıması olan Heidi, Viking Vicky animasyon filmlerinde yer alan akıl, cesaret ve hoşgörüyle zorluklarla mücadelenin aksine doğaüstü bir evrende, kötülükle savaşan iyilik perilerinin atanmış sihir ve dışardan gelen yardımla mücadele anlayışı sorgulanacaktır.

Anahtar sözcükler: Kapitalizm, tüketim, güzellik, Winx perileri, Heidi, Viking Vicky

\section{Giriş}

Film,özünde etkileyici bir sanat türüdür. Filmler, sinema dünyasının sunumu yoluyla merak uyandıran sempatik karakterler ve görsel issitsel araçlarla duyguları ortaya çıkarmaya çalışmaktadır (Tarvainen vd., 2015). Çizgi filmler, daha çok çocukların davranış ve tutumlarını etkilemektedir. Cocukları olumlu veya olumsuz

\section{Winx cartoon series as aesthetics of beauty consumption with mental messages on cosmetic products \\ Abstract}

Produced by the Italian Iginio Straffi, the Winx Club animated series is about a fantastic universe where fairies, witches and mythical creatures live together. Straffi prefers to use common Japanese manga (comics) with Western elements for the design process of the animated film. The physical appearance of the fairies were designed to the look like of popular stars such as Beyoncé, Jennifer Lopez and Kim Kardashian. Straffi's Rainbow SpA combined with Viacom (US media company) after becoming internationally popular of the movie beyond expectations. The ongoing series of the film after partnership with Nickelodeon, display an example of American consumer culture that is growing importance of physical appearance and perfect beauty with constantly changing costume. Whether or not there is a consensus on exactly what is beautiful is one of the issues that have preoccupied thinkers since ancient times. What makes something or someone beautiful, whether it is a feature of a person or an object, is rather in the eye of the bebolder. However, Winx Club series contain images that encourage luxury consumption and cosmetic surgery in the fictional universe of perfect beauty' which there is no connection between soul and beauty. I try to explain to perfect beauty ideal on capitalist society and in what ways, changing our body easily, via Winx fairies' exaggerated physical appearances, which give encouraging signals for luxury cosmetic products. On the other hand, I will explain the differences between Winx Club with Heidi and Viking Vicky films for significant social messages.

Key words: Capitalism, consumption, beauty, Winx fairies, Heidi, Viking Vicky

etkileme gücüne sahip çizgi filmler, çocukların günlük alışkanlıklarından biridir. Zira, çocuklar gelecekteki karakterini etkileyecek her türlü bilgi ve tesiri kabul ederler (Wijethilaka, 2020). Winx Club çizgi film serisi, özgürlük, zekâ, birey, dayanışma, dürüstlük, çallşkanlık, kendi kendine öğrenme ve kendini gerçekleştirme gibi kavramlarıiçinde barındıranklasik liberalizm düşüncesel 
yansımasının izlerini taşıyan Heidi, Viking Vicky gibi çizgi filmlerden önemli ölçüde farklılık göstermektedir. Zira Heidi çizgi filminde, doğada koşan oynayan, kendi kendine yaparak öğrenen, birkaç kez ölüm tehlikesi ile yüzleşen Heidi karakteri çok mutludur. Mainfeld kasabasında büyükbabası ile yaşayan Heidi, karşılaştı̆̆1 her sorunu kıvrak zekâsı, hoşgörüsü, dürüstlüğü ve insan sevgisi ile çözmektedir. Kasabadaki tek dükkânın sahibinin kızı Teresa ise kıskanç ve sıkıştığı zaman yalan söyleyen bir karaktere sahiptir. Ancak Heidi herkesle iyi geçinir ve tüm sorunlarını yüz yüze iletişim, akılcılık, sevgi ve dayanışma ile çözmektedir. Heidi, sevginin her şeyi iyileştireceğine inanmaktadır. Nitekim tekerlekli sandalyedeki arkadaşı Clara Sesemann'nın iyileşmesine ve kuralcı nedime Bayan Rottenmeier'n yumuşamasına da yardımcı olur. Gerek annesinin ölümü ardından yürüyemeyen ve içine kapanan Clara için gerek aç gözlü ve kıskanç Teresa için Heidi dostluk ve sevginin, dürüstlük ve dayanışmanın sihridir. Heidi, tüm zorluklar ve olumsuzluklarla içinden gelen güç sayesinde savaşır. Zira Heidi'nin gücü, insanın içinden gelen yaşama ve mücadele etme yeteneğidir (Küçük, 2019).

Winx perilerinin sihirli güçleri vardır. Kötülükle mücadeleyi, sihirli güçlerini birleştirerek yapmaktadırlar. Nitekim dışarıdan gelen ve kendinden olmayan bir güç söz konusudur ve mücadele yeteneği kendinde aranmaz aksine dışardan atanır. Nitekim Heidi ve Vicky'den farklı olarak, her bölümde periler en az üç-dört kez kıyafet değiştirirken, topuklu ayakkabıları, uzun tırnakları, makyajlı yüzleri ve podyumda yürüyen mankenlere benzer beden ölçüleri ile gözlere hitap ederler. Valtor'un Kutusu bölümünde Bloom ve arkadaşları arasında geçen konuşmada "Haydin Magic'de alışveriş yapalım. Bu yağmurluklar Valtor'dan (sihirli güçleri olan kötü adam) bizi koruyacak, kraliyet terzisi sağ olsun" denmektedir (Winx Club Türkiye, 2015a).

Diğer yandan, Winx Club Kayıp Kralliğın Sırrı isimli sinema filmi, Winx serinin ilki olmakla birlikte farklı dillere çevrilerek 22 Şubat 2008'den itibaren birçok ülkede gösterime girmiştir. Filmde Winx perilerinin mezuniyet gecesi de vardır. Altı perinin süslü püslü giysileri ile katıldığ1 gecede Flora, Stella isimli periye "Brandon yeni ayakkabılarını görsün" der. Diğer peri ise, "Üzerinde bu elbise varken Brandon ayakkabılarına bakar mı"demektedir. Bir diğer peri ise şöyle der: "Ben her zaman söylerim popülarite gücü de beraberinde getirir". Bu bölümde geçen şark1 sözleri de bir hayli ilginçtir: "Kolay değil, farklı olmak ve inanmak görünmeyene." Kayıp Krallı̆ın Sırrı bölümü sonunda krallığ1 kurtaran ve ailesini bir araya getiren Bloom, sevgilisi Sky ile buluşur, dansa başlamadan bir peri arkadaşı şöyle seslenir: "Hey Bloom, dans sensiz başlamıyor, yeni elbiseni herkese göstermen gerekiyor" (Turkay GT, 2020).
Baudrillard'a göre, yokolmuş sadeliğin yerini lüks tüketim alırken, moda ise kısıtlama olmaksızın her türlü değer yargısı ile oynamaktadır: Yeni ve eski, güzel ve çirkin, ahlaki ve ahlaka aykırı durumlar üzerinde kalıc1 tesirlere neden olabilmektedir. Baudrillard için ihtiyaçtan fazla tüketim, çeşitli sağlık problemlerine yol açmaktadır. Örneğin, kolit, uykusuzluk, bazı kaşıntı veya egzama türleri, cinsel zorluklar, obezite, solunum, sindirim veya kardiyovasküler problemler gibi birçok sağlik sorununa neden olabilmektedir. Diğer bir husus ise Calvin Klein reklamlarını süsleyen ve gittikçe yaygınlaşan cinsel açıdan belirsiz, hermafroditik modeller ile zindeliğe artan ilgi; zayıflık arzusu ve bunun sonucunda ortaya ç1kan diyet çılgınlığı; düşük kalorili, az yağlı yiyeceklere olan saplantı; ve cinselliğin ticari amaçlarla artan kullanımı. Geçmişte şişmanlık ve obezitenin güzellik olarak algılandığ1 zamanlar olmakla birlikte günümüzde evrensel güzellik anlayış1 zayıllıkla bütünleşmiştir (Baudrillard, 1997).

"Estetik" veya kozmetik cerrahiye son y1llarda artan talep, gençliğe ve güzelliğe karşı değişen değer yargılarını yansitmaktadır. Amerikan Plastik Cerrahlar Derneği verilerine göre, 2003 y1lında 8,7 milyondan fazla kişi estetik ameliyat olmuştur. Bu oran bir önceki yıla göre \%33 artarken, 1992'den bu yana \%1698 artısla estetik endüstrisi inanılmaz boyutlara ulaşmıştır (Honigman ve Castle, 2006).

Türkiye'de kozmetik ve estetik endüstrisine ait merkezi bir istatistik otoritesi ile yasal veri toplama kaynaklarında eksiklik nedeniyle, gerçek veriler bilinmemektedir. Ancak, güzellik uğruna yaygınlaşan mide küçültme, yağ aldırma, dudak dolgunlaştırma, Fransız ask1sı gibi estetik operasyonlar artarken, İstanbul'da bir güzellik merkezinde botoks yaptıran 38 yaşındaki kadın yakın bir tarihte hayatını kaybetmiştir. Botoks yapan ve güzellik merkezini işleten kişinin ilkokul mezunu olduğu ise soruşturma sonrası öğrenilmiştir (“Kübra Boyraz'in botoksu”, 2020). Hayatını kaybeden kadın ekranlarda gördüğümüz sanatçı ve modellere benzemek için defalarca estetik ameliyat olmuş ve salgin nedeniyle artan vakalar dahi botoks yaptırmasinı engelleyememiştir. Bir diğer ilginç haber ise, internette gördüğü bir botu satın almak üzere bir haftalık bebeğini satışa çıkaran 25 yaşında ki Rus anne ile ilgilidir. Parası olmadığ1 için botu almak üzere bebeğini internetten satışa çıkardığını söyleyen kadını ise, müşteri kılı̆̆ına giren polisler yakalamıştır ("Ayakkabı alabilmek için", 2020).

21. yüzyılda, güzellik ve mükemmellik kavramı, daha fazla özendirilmekte ve beden üzerinde estetik cerrahi müdahaleler artmaktadır. Sadece kadın bedeni değil erkek bedeni de estetik cerrahi ve güzellik endüstrisinin hedefindedir. Bu makale, değişen değer yargıları ve kimlik ile kendini ifade etme aracı olarak güzellikgençlik olgusuna artan odaklanma nedeniyle özendirilen 
estetik cerrahi hususuna değinmektedir. Nitekim Winx çizgi film serisi ile üretilen tek tip güzellik ve estetik tüketim olgusu, Heidi, Viking Vicky çizgi filmlerinin doğallık ve akılcılık felsefesi ile tezatlık taşımaktadır. Yaşlanma sürecini tersine çevirmeye çalışan kozmetik yöntemler de aşırı bir artış yaşanırken, genç bir görünüm, modern toplumda takıntı haline gelmiștir. Zira daha çok içeriğinde klasik liberalizm öğretilerini (birey, özgürlük, akıl, kendini gerçekleştirme, özerklik, hoşgörü...) barındıran tanınmış çizgi filmlerden Heidi ve Viking Vicky'nin tersine bedenin bir tüketim öznesi olarak konumlandırıldığı tektipleşen dış görünüş anlayışı ile dışardan gelen atanmış bir gücü (özerklik karşıtı) empoze eden Winx çizgi film serisi gerek mesajları gerekse görselleri ile büyük farklılık taşımaktadır. Bu çalışmanın amacı genellikle kız çocukları tarafindan izlenen Winx çizgi film serisinin lüks tüketim, ve beden güzelliğini özendiren dialogları üzerinden söylem analizi yoluyla olası etkilerini değerlendirmektir. Aynı zamanda klasik liberalizm unsurlarını barındıran Heidi ve Viking Vicky ile Winx animasyon filmi karşılaştırılarak değişen değerler ve postmodern toplumda artan lüks tüketim anlayışı sorgulanacaktır. Nitekim diş görünüşe olan ilgilinin artması ve fiziksel görünümün nesneleşmesi ile değişen güzellik anlayışının görsel medya araçları üzerinden estetik cerrahi operasyonlarını teşvik etmesi ve sonuçlar1 sorgulanacaktır.

\section{Ahlaki yatırım olarak çevresel duyarlılık ile lüks tüketimin kutuplaşması: Winx Çizgi Filmi'nin iki yönü}

Neredeyse her türlü üretimin küresel sermaye akımları tarafindan gerçekleştirildiği, günümüzde giysilerimizin, yiyecek ve içeceklerimizin, arabalarımızın yanı sıra izlediğimiz filmlerin üretim yerleri ve aidiyetleri farklı farklı uluslara aittir. Pekçok ulusal nüfuz alanında şubeleri olan çok uluslu şirketler, bilhassa küresel multimedya şirketleri, neoliberalizmin devamını sağlayacak tüketim toplumu için çaba sarf etmektedir (Güven, 2009).

Ritzer (2011), modern toplumların kültür ve medya emperyalizminin varlığıyla karșı karşıya olduğunu vurgulamaktadır. Kültür emperyalizmi, bir kültürün diğer kültürlere göre baskın olması nedeniyle ortaya çıkmaktadır. Böylece, sanatın mekanik olarak yeniden ortaya çıkışı, kültürel çıkarların sınıfa yayılma eğilimiyle sonuçlanmıştır. Günümüz dünyasında medya emperyalizmi, daha az gelişmiş toplumlarda ve kültürlerde Batı medyasının ve teknolojilerinin hakimiyetinin bir sonucu olarak ortaya ç1kmaktadır. Ritzer (2011) için, sömürgecilik bu tür emperyalizmin bir sonucudur. Kültürel sömürgecilik, bir kültürü dünyanın diğer bölgeleri üzerinde bir siyasi ve ekonomik kontrol aracı olarak empoze etmektir. İngiliz dilinin evrensel kullanımı, genel yaşam tarzları yanısıra yeme-içme kültürü buna örnektir. Ritzer, Doğu'nun Batı üzerindeki ekonomik ve kültürel etkisine vurgu yapmaktadır. Doğu etkisine örnek olarak Ritzer, etnik restoran ve mutfakların (Çin, Hint, Japon), yoga, vejeteryanlığın ve otomobil endüstrisinin (Toyota, Nissan, Honda, Hyundai) ve elektronik endüstrisinin (Sony, Panasonic) artan popülaritesini göstermektedir (Frisk ve Yoshida, 2005; Ritzer, 2011).

Zamanımızın odak noktası lüks tüketim, COVID-19 salgınında bile azalmamıștır. Tüketime bağlılık ulusal ya da uluslararası şirketlerin kurumsal sorumluluklarını artırmaktadır. Etik, özünde ahlak felsefesi anlamına gelmekle beraber, bireyin bütün eylem ve davranışlarının kökenini kapsayacak şekilde, ahlaki kural ve davranışları felsefik açıdan inceler. Etik kavramının felsefe açısından alanı, iyi ve kötü (doğru ve yanlış) fikirler arasında ahlaki bir seçim yapabilmektir. Ahlak ise, bireyin kendi doğruları ve bakış açısı ile inandığı kurallar ile yaşadığı toplumca benimsenen ve paylaşılan kültürel değerlerin toplamıdır (Özer ve Sinav, 2009).

21. yüzyllda şirketler kurumsal sosyal sorumluluk ve ahlaki yatırım konularına artan şekilde son yirmi yılda daha fazla ilgi göstermektedir. Esasen sosyal sorumluluğun demokratik süreç içinde yerini anlamaya çalışmak, sosyal sorumluluk literatürünün kurumsal dünyanın ötesine geçmesini sağlamıştır. Dünya Bankası'na göre, “kurumsal sosyal sorumluluk, işletmelerin çalışanlar, aileleri, yerel toplum ve genel olarak toplumla birlikte çalışarak iş ve kalkınma için yaşamlarını iyileştirmek için sürdürülebilir ekonomik kalkınmaya katkıda bulunma taahhüdüdür." Örneğin, Dünya Sürdürülebilir Kalkınma İş Konseyi kurumsal sosyal sorumluluğu, "genellikle toplum ve yerel topluluk ile birlikte onların aileleri ve işgücünün yaşam kalitesini geliştiren ekonomik kalkınmaya katkıda bulunan iş dünyasında etik davranma taahhüdüdür" şeklinde yorumlamaktadır (Neu ve Gomez, 2006).

Her ne kadar kurumsal sosyal sorumluluk konusuna artan bir ilgi olsa da, bazı firmalar tüketici sağlığını kâr amacının çok gerisinde tutmaktadır. Nitekim pek çok bisküvi, şekerleme, tatlı vb. ürünlerde kullanılan palm yağı bazı bilim insanlarına göre insan sağlığına zararlıdır. Nestlé, Hollanda menşeli bir çok uluslu şirkettir. Bu firma, Türkiye'de satışa sunduğu kahvaltı gevrekleri için neredeyse hiç talep alamamış, ancak kalvaltı kültürümüze uygun olmayan kahvaltı gevreklerini uzun soluklu ve sürekli bir reklam ve kampanya çalışmaları sonrası belli bir pazar payına ulaştırmayı başarmıştır. Nestlé firmasının ürettiği pekçok mamülde kullandığı palm yağını yağmur ormanlarına zarar veren "Sinar Mas" isimli bir tedarikçiden temin etmesi ise Green Peace sivil toplum örgütünün tepkisini çekmiş ancak beş y1l süren mücadele sonrası Nestlé, palm yağını takip edebilir üretici ile sorumlu kaynaklardan temin etme yoluna gitmiştir (Çubukçuoğlu, 2017). 
İletişim ve enformasyon teknolojilerinde yaşanan gelişmeler neticesinde, yaşamımızın her alanında, kitle iletişim araçları vasıtasıyla reklam, çizgi filmler, ürün yerleştirilen dizi filmler ve programlar, özendirici filmler ve yayınlar ile kapitalizmin tükettiren teması "topluma egemen söylemlerin ortaya çıımasında" anahtar rol oynarken, aynı zamanda toplumun "tasarruftan arzu kültürüne yönelmesine" adeta ön ayak olmaktadır (Demirel ve Yegen, 2015, s. 122). Nitekim, üretim ya da çalışma insanın bir tarafı iken diğer tarafı ise tüketimdir. Zira, Esin'e göre endüstri çağının, giderek artan oranda, daha bağımlı ve otomatikleşen bir gerçeğidir tüketim. Ancak, tüketicinin pazarda serbestçe seçme ve yeğleme hakkı varmış gibi gözükürken, bilinçaltına yerleştirilen imgelerle mutluluğun ana kaynağı şeklinde gösterilen tüketim vasıtasıyla potansiyel tüketiciyi otomatik bir tüketim mekanizmasına dönüştürmektedir. Bunun benzeri görülmemiş etkileşim süreci tıpkı Sanayi Devrimi sonrası işçinin çalışma makinesine dönüştürülmesine benzer. Ancak bilinç altı yönetişim mekanizmaları ile üretilen tüketim arzusu, özgürlüğü ve iç huzuru sağlamamaktadır (Esin, 1982).

Nitekim günümüzde, toplum faydasına değişen beklentilere ve değerlere cevap veremeyen veya önemsemeyen kurumlar, bir takım eleştirilere maruz kalmaktadır. Firmaların kendi çıkarları ile toplumun iyiliğini birleştiren bir ahlaki yapıda olması beklenmektedir. Bilhassa kurumsal sosyal sorumluluk ve toplumun kültürel değerleri arasında yadsınamaz bir ilişki vardır. Zira ticari bir işletmenin, etkileşimde bulunduğu toplumun kültürel değerlerini önemsemesi, ilgiyi artırarak satışını etkilemektedir (Ertürk, 2009).

Winx Club: Okyanusun Gižemi isimli animasyon türü çizgi filmin başlangıcında bir petrol gemisinin ürettiği kirliliği görürüz, atık petrol varili okyanusa petrol sızdırırken, tüm deniz siyaha boyanır, balıklar kaçışır. Ardından okyanusa gelen Trix kızları arasında şöyle bir konuşma geçer: "İnsanlar dünyanın tüm okyanuslarını kirletiyor bu da sonsuz okyanusların dengesini bozuyor." “Okyanuslara hâkim olmanın tam zamanı.” Diğer tarafta, Winx kızları hazırlanmış Stella'yı beklemektedir. İçeriden Stella, "Olamaz!" diye bağırır. Stella'ya cevap veren peri, "Çabuk ol, bu yılki yeni öğrenciler bizi bekliyor." der. Bir diğeri, "Zaten bir dakika otuz beş saniye geciktik bile." der. Öteki, "Belki bir sıkıntısı vardır." derken diğeri "Stella'y1 tanıyorsam son moda gözlüklerini arıyordur." der. Bloom ise "Saçmalama canım. Stella hiç gözlük takmaz ki." der. Stella aşırı havalı gözlükleri ile merdivenlerde belirir. Hepsi gülüşürler, Stella "Ne olmuş?" diye sorar. Bloom "Stella, sen eşsiz birisin." der. Stella ise "Ne yapayım? Gösterişli olmak doğamda var" der. Öğretmenlerinden azar işittikten sonra yeni öğrencileri karşılamaya giderler. Sahneye çıtıklarında Stella 1şıkları karartır ve "Spot sşıkları harika olduğum yer." der. Diğer peri "Stella yapma! Bu bir defile değil." derken diğeri ise "Ama şurası kesin ki şimdi dikkatlerini çektik." der. Okyanusun Giz̧emi filmi gençlere, çocuklara, yetişkinlere ve ebeveynlere yöneliktir. Zira kimyasal atıklarla kirlenen okyanusu kurtaran, kahraman Winx perileri, aynı zamanda yukarıda verilen konuşma alıntısında olduğu gibi gösterişli kıyafetleri, dikkat çekici dış görünüşleri ve podyumda manken gibi yürümeyi doğal bir olgu gibi gösteren tek tipleşmiş fiziksel görünüş üzerinden tüketim özendiricileridir. Zira, ne Winx perileri ne de yeni öğrenciler vücut ölçüleri ve tarzları bakımından birbirinden farklı bir kültürel motif taşır. Hepsi aynı çekik gözlere, aynı vücut ölçülerine ve aynı heveslere sahiptir. Yapımcı Straffi, bir taraftan bir ahlaki yatırım olarak okyanusların kirlenmesi konusunu ele alırken, esasen, gösterişli tüketim toplumuna yönelik imgeler, söylevler ve görsellerle dolu bir sinema filmi yapmiştır (Winx Club Türkiye, 2014).

Winx perileri arasında doğa perisi olan Flora hoşgörülü, iyi kalpli ve bir doğa koruyucusudur. Tek Boynuzlu Atm Sırr bölümünde pandaları, Canavar ve Söğ̈̈t Ağac bölümünde bataklığı, başka bir bölümde küresel ssınmadan turnaları kurtarırlar. Doğaya saygı duyan ve koruyan Winx perileri, okyanusların kirlenmesi, iklim değişikliği, hayvanların ve bitkilerin yok edilmesi gibi tüm doğal felaketlerin nedenini kötü sihir olarak gösterirken, çözümü ise iyi sihirle gerçekleştirmektedirler. Oysaki küresel ısınma, yabani hayatın tehlikeye girmesi, hayvan ve bitki çeşitliliğinin azalması, sanayileşme ve tüketim toplumunun eseridir. Anne ve babalara yönelik ahlaki yatırım olarak sunulan çevresel duyarlılık ile -bilhassa parlayan güneş perisi Stella'nın koluna konan bir uğur böceğinden dahi tiksinmesi- her zaman bakımlı makyajlı ve şatafatlı görünümlü, tüm son moda teknolojik aletlerini kullanan periler ile büyük tezatlık taşımaktadır. Zira doğayı sevmeyen nasıl doğanın koruyucusu olur?

\section{Satın alınan ve tüketilen güzelliğin esareti}

Von Schiller'e (2017, s. 20) güzellik bir bütünlüktür, kişinin bütün kabiliyet ve içgüdülerinin birleşmesi ile elde edilen güzel bir ahenktir. Gerçek güzelliğin oluşabilmesi için içgüdülerin asilleşmesi gerekmektedir ve buna yardımcı olan tek araç sanattır. Von Schiller için, zor devleti hürriyet devletine dönüştürebilecek olan yegâne şey halktır ve oluşturulan halk kültürü bu hususta önemli bir rol oynar. Kültürün gelişmesinde en önemli nokta ise aklın ve güzelliğin geliştirilmesidir. Ortak faydaya ve akıl yürütmeye dayalı kabiliyet ve içgüdülerin geliştirildiği bir doğal kültürel denge halkı özgürlüğe götürebilir.

Winckelmann (akt. Jahn, 1867) için doğa ve insan güzellik içinde birlikte yaşarlar. Doğanın güzelliğinde, insanların hem canlı sanat eseri hem de doğanın en yüksek tezahürü olarak kendi güzelliğini yaşamasına izin veren bir "şenlik ve oyun" an1 meydana gelmektedir. 
Zira Winckelmann, insan güzelliğin “"asalet ve sadeliğini” vurgulamıştır (Winckelmann, 1867 akt. Jahn, 1867).

Ancak küreselleşen dünyada, yerel toplumları özgürlüğe götürebilecek bir doğal kültür yerine giderek yaygınlaşan bir tüketim kültürü söz konusudur. Tüketici Kültürü'nde Per Lury şöyle demektedir: “İnsanların sosyal olarak birbiriyle ilişki kurmalarının en önemli yollarından biri, tüketim nesnelerininin arabuculuğu ile olmaktadır." Böylece, tüketim ekonomilerine katılım karşılı̆̆ında kimliğin keşfedilmesi sağlanır (Bosse, 2007, s. 37). Zira yaşamımız, duygularımız ve tavırlarımızın, antropolojik bilgiler ışı̆̆ında birbiriyle kenetli bir şekilde yaşadığımız çevre ve kültürle ilişkilidir (Bulut, 2005).

Küresel Güzellik Endüstrisi isimli kitabinda Jha, 21. yüzyılın on yılının bir paradokslar dönemi olduğunu söylemektedir (Jha, 2015). Bir yandan, Çin, Hindistan, Brezilya, Rusya ve Güney Afrika'da artan refah ve orta sınıfların gelişimi beraberinde diğer yandan iklim değişikliği, çevrenin bozulması, işgücünün sömürülmesi, kızları ve kadınları hedef alan cinsel istismar, sosyal medyaya devlet sansürü ve hükümet yolsuzluğu söz konusudur. Hindistan'ın neredeyse her yerinde çoğalan güzellik yarışmaları, tüketici endüstrileri, moda, yerel güzellik merkezleri ise çok uluslu şirketler tarafindan desteklenmektedir. Güzellik yarışması kazananların çoğunluğu, Bollywood film endüstrisi tarafindan film starı olmak üzere yetiştirilmektedir. Miss Hindistan güzellik yarışması, çok uluslu şirketlere aittir ve güzellik, moda ile eğlence alanına odaklanan, İngilizce konuşan orta sınıf kadınları hedeflemektedir. Nitekim bu yarışmalar, düşük gelirli orta sınıf kadınlar için sınıf atlama, kültürel ve malî gelişim sağlamaktadır. Böylece her genç kızın rüyası haline gelen güzellik yarışmaları, küresel güzellik endüstrisine katkıda bulunmaktadır (Jha, 2015).

Modern Batı toplumu başarı, gençlik ve güzelliği saplantı haline getirmiş durumdadır. 20. yüzyılın ikinci yarısindan bu yana, kimlik ve kendini ifade etme arac1 olarak fiziksel görünüşe ilgi büyüyerek artmıştır. Gençlik, yaş ve yaşam deneyimlerinden daha değerli ve ayrıcalıklı hale gelmiştir. Güzellik, sosyal değerin görünen yeni göstergesidir. Esas olarak bu durum, yaşa sayg1 duyulan ve yaşlilara olan hürmete dayalı kültürlerle de çelişmektedir (Honigman ve Castle, 2006).

Giderek yaygınlaşan estetik endüstrisi ile gençlik ve güzellik tutkusu, esasen Amerikalıların içine düştüğü bir girdap gibidir. Zira Amerikalıların büyük çoğunluğunda "bedensel güzelliğin her kapıyı açarak, para ve şöhreti getireceği" yönünde bir alg1 vardır. Hollowood'un gençlik tercihi, uzun süredir yayg1n olarak kabul gören bir olgudur. 1920'lerin sonlarına doğru şekillenen bu gençlik tutkusu, gün yüzüne çıkan bir tüketici kültürünün ürünüdür. Wallman'a göre (2018), ABD'de tüketim kültürü 1920'lerden daha önce oluşmuştur. Amerikan halkı, 1800'lerde tek kullanımlık tıraş bıçaklarını tüketirken, gömlek yakaları ve manşetlerini ise beyazlatılması zor olduğundan atmaya ve yenisini kullanmaya başlamışlardır. 1800'den önce, Prütenlerin diyalektik yaşlanma inşası, kişinin son yıllarına dair, çelişkili ama umut verici bir vizyon sunmuştur. Böylece, muhtemel hastalıklar ve sakatlıklar kadar yaşlılığın telafi edici manevi potansiyelide öne çıkarılmıştır (Addison, 2006; Wallman, 2018).

Zamanla artan rekabet ve üretimdeki verimlilik ve sanayileşme tüm alanları etkilemiştir. Kadınların çekiciliği "değişim" değerlerinin önemli göstergeleri haline gelen gençlik ve güzelliğe sahip olmalarına bağlı olmuştur. Böylece, her geçen yıl ironik bir şekilde yılların sektör deneyimine sahip kadin yıldızlarına daha az rol verilmekte ve bu yıldızların yapımları azalmaktadır (Addison, 2006).

Baudrillard'a (1997, s. 160) göre "Güzellik, sanki dinsel, mutlak bir buyruğa dönüşürken, kusursuz, şaşalı şekilde bir soyut biçime bir haz ve arzu nesnesi olarak moda etiğinin içine hapsolmuştur." Öyle ki, bir tüketim öznesi olan beden, bireyin kendisi ile toplum arasındaki etkileşimi sağlamak üzere konumlandırılır. Bireyin daha iyi bir bedene sahip olmak için gösterdiği çaba, harcadığı zaman ve para, onaylanmak ve iyi bir yaşam sürebilmek içindir (Dedeoğlu ve Savaşçı, 2005).

Güzelliğin, duru ve sade, abartıdan uzak, yanakları pembeleşen hafif utangaç, kuğu boyunlu, zarif, nazik bir zerafet ve görgü ile anıldığı dönemlerin çok gerisinde kaldık. 21. yüzyılda fitness merkezlerinden birinin internette verdiği haber ve reklam içeriğinde şöyle yazmaktadır: "3 Çocuk Annesi Megan Fox'un Seksi Vücudunun Sırları." Alt başlıklar olarak, hem kariyer hem çocuk ile diyet konusunda oldukça titiz yazmaktadır. Başlıkları Megan Fox'un oldukça cüretkâr fotoğraflar1 süslemektedir (Akagün, 2019).

Ünlülerin fitness eğitmeni Tammy Hembrow, internet ortamındaki fitness kanalıyla kısa zamanda büyük bir kazancın sahibi olurken, 9 milyonun üzerinde takipçisi vardır. Kanalında yaptı̆̆ı her sözleşme için ortalama 17 bin dolar kazanan Tammy'nin aynı zamanda bir giyim markası da bulunmaktadır. Sarı uzun saçları, ince beli, kaslı vücudu ve iki çocuğu ile poz veren Tammy, hem iki çocuk doğurmuş hem de ideal ölçülerini korumuş biri olarak, servetine servet katmaktadir. Tammy Hembrow'un Instagram sayfasını açtı̆̆ınızda, kısa kısa videolar ile karşılaşırsınız. Birinde arkadan çekilmiş ağırlık kaldırma videosu, diğgerinde lüks evinin yüzme havuzunda oğluyla verdiği pozlar vardır. Jennifer Lopez, Kim Kardashian tarzı vücudu, sarı uzun saçları, takma kirpikleri, ojeli tırnakları ile ünlülerin replikası gibidir (Ünlülerin fitness eğitmeni, 2019).

Böylece, sosyal medya ve kitlesel iletişim teknolojileri ile giderek büyüyen lüks tüketim, bir zümrenin hakimiyeti dişına çıkarken, topluma yayılmaktadır. Lükse ilgi duyan, sosyo-ekonomik yapı çeşitlenirken, bu durumda 
yaygınlaşan iletişim teknolojileri vasıtasıyla yeni tüketici gruplarına ulaşmak ve kitlesel lüks tüketimi özendirmek zor olmamaktadir. Dikkat çekici bir şekilde, televizyon, sosyal medya ve radyo programları aracılı̆̆ıla güzellik ve estetik üzerine verilen reklamlar ile sağlıklı yaşam programlan, internet bilgileri, gazete ve dergiler, TV dizileri, estetik uzmanlarıyla söyleşiler vb. lüks tüketimi özendirmektedir (Oral, 2014).

İnsan bedeni, toplumun ekonomik, kültürel, dinsel ve politik yapılarının içinde şekillenen, toplumsal aktörler tarafindan tekrar tekrar üretilen ve toplumsal gerçekliğin anlaşılmasında bize kaynaklık eden kültürel haritalardir. Zira postmodern kültürün günümüzdeki doğasına uygun olarak güzel bedenlerin teşviki, yaş grubu ve cinsiyet ayırımı olmaksızın, estetik cerrahiye yönelimi artırmıştır. Görsel medyada sunulan ve kusursuz gösterilen tek tip bedenler, estetik cerrahiye başvuranların sayısını günden güne artırmaktadır. Nitekim estetik cerrahinin yükselişinde, tıp alanındaki teknolojik gelişmeler ile acının hafifletilmesi ve operasyonların hılanması, bedenin dinsel baskıdan özgürleşmesi, sosyal medyada sunulan imajlar, güzellik sırları, ünlülerin yaşamları, filmler ile görsel ve işitsel medya yoluyla tek tip güzellik idealinin yaygınlaşması mümkün k1lınmaktadır. Zira günümüzde cinsiyet, ırk, dil, din farkı olmaksızın güzelliği elde etmek üzere kadın, erkek, genç yaşlı herkes, hayati risk taşımasına rağmen, estetik müdahale olmak istemektedir (Gürler, 2018).

Oysaki, Ş. Sami'nin Kadinlar isimli eserinde, Enderunî Fazıl tarafindan kaleme alınan (kadına dair yazılan eser) Zenanname'de ve diğer divan edebiyatı eserlerinde kadın güzelliği aşk kadar önemlidir. Ancak Osmanlı'da sosyal, etnik ve dinsel olarak farklı kadınların yer aldığı bir kültürel çeşitlilik içinde tek tip bir kadın yoktur (Güzel, 2013).

Plastik cerrahi başlangıçta askerî doktorlar tarafından savaşta yaralanan askerlerin yaralarını iyileştirmek, yüzlerini ve bedenlerini önceki ideal ölçülerine ulaştırmak üzere kullanılmıştır. Plastik cerrahinin günümüzde tanımı ise "Görünüşü ve benlik sayg1sını iyileştirmek üzere vücudun normal yapısını yeniden şekillendirmek için cerrahî ve cerrahî olmayan prosedürlerdir." şeklinde değişmiştir (Abelsson ve Willman, 2020, s. 1). Beden imgesi, bir kişinin bedeniyle ilgili algıları, beklentileri ve hisleridir. Beden imgesi, görünümün kişi için ne kadar önemli olduğundan etkilenir (Abelsson ve Willman, 2020). İzmit'in Derince ilçesinde yaşayan ve 89 kiloya çıkan iki çocuk annesi Dilek Utar'ın, oğlunun sünnet düğünü öncesinde özel bir klinikte yağ aldırma operasyonu ardından komaya girmesi ve yapılan tüm müdahalelere rağmen ameliyattan bir gün sonra vefat etmesi, çok trajik ve aynı zamanda toplumun geldiği noktayı yansıtan, acı veren bir hadisedir (Yağ aldırma, 2018).

\section{Post modern tüketim kalıplarının çocuklara yansıması}

Amerikan Pediatri Akademisi, dijital medya ile televizyon ve bilgisayar ekranların aşırı kullanımının çocukları ve gençleri obezite, uyku sorunları, siber zorbalık ve okulda olumsuz performans riski altına sokabileceği hususunda uyarmıştır. 2015 Common Sense Media raporuna göre, 8 ila 12 yaşındakiler için her gün ekran karşısında harcanan ortalama süre 4 saat 36 dakikadır (Bhattacharjee, 2017).

Avustralya'da ailelerin üçte biri üç ya da daha fazla televizyon sahibi iken, çocukların \%20'sinin odasında kendine ait televizyon bulunmaktadır. Oysaki, fazla televizyon seyretmeçocuklardaodaklanmaproblemlerine yol açmaktadır. Küçük yaşlarda (1-2) televizyon seyretmeye başlayan çocukların \%28'inde, 7 yaşına gelindiğinde odaklanma problemi gözlemlenmektedir. Hiperaktivite ve dikkatsizlik ise aşırı televizyon seyretme ile yakından ilişkilidir. Diğer taraftan aşırı televizyon seyretme çocuk ebeveyn arasındaki etkileşimi miktarını ve kalitesini olumsuz etkilemektedir (Slee, 2002). Postman'a göre (2004), televizyon yeni epistemolojinin kumanda merkezidir. Öyle ki, küçük, büyük, yoksul, zengin, genç ihtiyar pekçok birey televizyon izlemekten kendini alıkoyamamaktadır. Kamuoyunu ilgilendiren tüm konular, televizyonun ilgi alanında iken, en iyi eğitim sistemi bile televizyonun halk üzerindeki etkisini azaltamamaktadır (Postman, 2004).

Modernleşmenin erken döneminde bilhassa Sanayi Devrimi sonrası çalışma etiğinin yükseldiği ve daha çok üretici olarak konumlanan birey, postmodern dönemde tüketici konumuna evrilmiştir. Postmodern dönemde tüketiminin demokratikleştiği, tüm diş çevrenin medya donanımlı rol modeller ile çevrelendiği görülmektedir. Beğenilme motivasyonu, tüketim toplumu içinde farklı bir bağımlılık ve onay isteği üretmektedir. Böylece kişinin, bireysel fayda ile içselleştirilen davranış kalıpları yerine akranları tarafindan onaylanmak isteği daha önemli hale gelmektedir (Tunç, 2017).

Bauman'a (1999) göre, tüketim toplumunun tercih özgürlüğünü, tüketicilerin iyi yaşam imajına yönelik çabaları belirler. Nitekim özgürce yapılan tercihlerin sayisı ne kadar fazla olursa, bireyin toplumsal hiyerarşide edindiği saygı o kadar yükselir. Kazanılan gelir ve zenginliğin tercih özgürlügüunde ürettiği etki önemlidir, zira yoksulluk/yoksunluk bireysel tercihleri sinırlamaktadır (Bauman, 1999).

\section{Post modern tüketim kültürü ve çizgi film}

Kapitalizmin ilk defa 16. yüzyılda Batı Avrupa'da kalıcı olarak kök saldığı birçok bilim insanı tarafından kabul edilen bir olgudur. Böylece İngiltere, Hollanda, Kuzey Fransa ve Kuzey Batı Almanya'da ekonomik büyümeye neden olmuştur. Zaman içinde siyasî ve askerî güce çevrilen kapitalizm, Avrupa devletlerinin 18. yüzyılın 
sonundan itibaren dünyanın geri kalanına hükmetmesini mümkün kılmıştır. Aynı zamanda, Avrupa'ya diğer kültür ve medeniyetlere karşı derin bir üstünlük duygusu kazandırmıştır (Heller, 2011).

İnsan aklının her şeyin ötesine geçtiği Aydınlanma Çağı, İngiliz Sanayi Devrimi'nin oluşumuna olumlu katkıda bulunurken, diğer taraftan ABD'de başta olmak üzere Fordist kitle üretimin devamı için tüketimi öncelemiştir. Nitekim postmodernizme geçiş süreçleri içinde tüketim toplumu ve tüketim kültürüne yönelik dönüşümü izlemek mümkündür (Batu ve Tos, 2017). Bir tüketim toplumu olan postmodern toplum, bir tüketim öznesi olarak gördüğü çocuklar ve gençlere yönelik pek çok film ve reklam üretmektedir. Bu filmler ile üretilen kahramanlar, çocukların ve gençlerin hayal dünyası üzerinde inanılmaz tesirlere özellikle zihin alt1 mesajlara sahiptir. Çizgi film kahramanları özgür, sihirli güçleri olan ve her istediğini yapmaya muktedirken, bu gerçek dışı hayal dünyasında ne yerel kültürel yaşantı ne de gerçek yaşama dair bir iz bulunmaktadır. Nitekim çocuklar ve gençler, bedenine, ailesine, kültürüne ve yaşadığı çevreye yabancılaştırılmaktadır (Karaboğa, 2018).

18. yüzyıl, “doğa", “akıl” ve "ilerleme” çağıdır. Aydınlanma Çağı'nda eleştirel düşünce, felsefenin odağına yerleşirken akıl ise kol kuvvetini geride bırakan en önemli güçtür (Alatlı, 2014). Özgün adı Vicky ve Güclü Adamlar (Wickie und die starken Männer) olan Viking Vicky filminin illk bölümünde Vicky'nin bir deniz korsanı olan babası Halvar, bir ganimet seyahatinden eve yeni dönmüştür. Eşine kolye ve saten kumaş, Vicky içinse bir borazan getirmiştir. "Vicky nerede?" diye sorduğunda annesi "Aşağıda gemide değil miydi?” der. Halvar, Ilvy'nin "Vicky kurt kovalıyor." dediğini hatırlar ve "Kurt bizim Vicky'yi kovalıyordur." der. Halvar Vicky'nin kendisi gibi güçlü, gözü pek birisi olamadığını söyler ve ekler: "Ben ki Viking'lerin başkanıyım." Annesi ise "Boş ver, bizim Vicky akılll." der. Halvar ise "O Vikinglerin en güçlü adamının oğlu, biraz daha güçlü ve kuvvetli olması gerekirdi." der. "Ben onun yaşındayken ta yukardaki ülkelerde ün salmıştım. Daha beş yaşında bile değildim ama kurt kovalıyordum!" der. "Ben, oğlum gibi çıt kırıldım değildim. Ben çok güçlüydüm. Biliyor musun?" diye ekler. Eşi ise "Bunu herkes biliyor. Sen işlerini kuvvet kullanarak yapıyorsun ama Vicky benim gibi ak1llı der." Az sonra Vicky sapasağlam gelir. Babası "Kurttan nasıl kurtuldun?” der, o da "Her zamanki ağacın tepesine çıktım." der. Babası "O korkağın teki!" derken annesi "Vicky hem dikkatli hem de akıllı, benim gibi." der. Annesi "İyi ki Vicky sana çekmemiş. O önce düşünür sonra harekete geçer." der. Halvar bunun üzerine Vicky'ye bir yarışma teklif eder. Vicky, kazanması karşılığında babasının onu gemiye almasını ister. 100 tane eşit büyüklükteki taşı uzakta bir ağacın altına taşıma yarışmasında Vicky bir kaldıraç icat eder ve taşları karşı tarafa fırlatarak yarışmayı aklını kullanarak kazanır (Nostalji Kasabası, 2017). Vicky deniz seyahatlerine gitme hakkı kazandıktan sonra kötü korsan (kaba kuvveti ile nam salmış) Swan'i her defasında aklı ile yener. Halvar'ın ve tüm tayfanın güvenini kazanır. Öyle ki Vikinglerin reisi Halvar, Vicky için "Sen öyle diyorsan oğlum.” diyecek kadar onu yüceltir. Ancak Winx perileri tam tersine, kötülükten ve kötü adamlardan akıllarını kullanarak değil, sihir yaparak kurtulurlar. Kendinden olmayan, dışardan atanan gerçek dışı ve kadercilikle ilintili bir başarı söz konusudur.

\section{Gerçek dışı bir mekânda, sihirli güçlerle savaşı kazanmak: Winx Club}

Her sinemasal imge gibi mekân da toplumsal, tarihsel, kültürel öğeleri içinde barındırır. 20. yüzyılı mekânın felsefesi olarak gören Foucault (2005, s. 292), mekânı, yan yananın ancak kopuk kopukluğun ve eş zamanlının, kesiştiği bir alan olarak değerlendirmektedir. Zira teknolojik gelişmelerin getirdiği noktada, mekân sanal ortamdır, varlık ile yokluk arasında, aynı anda ancak çok uzakta bizi doğadan ve gerçek yaşamdan ayıran bir dijital ortamdır. Esasen, 19. yüzyıl ile birlikte kentleşme ve yeni yaşam alanları oluşmuştur. Nitekim yaşadığımız bu kentler, yüksek gökdelenler, alısveriş merkezleri, mekânsal ayrıştırma ile zengin ve yoksulu birbirinden koparırken aynı zamanda doğa ile aramızda bulunan birer engeldir (Pösteki, 2019, s. 77).

Nüfusun artması ve tüketimin büyümesi ile ihtiyaç olmayanı üreten ve tüketimini teşvik eden kapitalist anlayışının tüm dünyada yaygınlaşması ve kentleşmenin boyutlarında inanılmaz büyüme sözkonusu olmuştur. Büyüyen kentler, insan ürünü sentetik varlıkları ile doğal olanı hiç olmadığı kadar tahrip ederek, yapay olanı ilerleterek, doğal edinme yollarını manipüle ederek, yaşam alanlarının büyük bölümünde doğal olmayanı egemen kılmıştır. Bu yıkıcı süreç ile aşırı büyüyen şehirler ve artan tüketim, doğanın yerine sentetik bir çevre üretmektedir (İşcanoğlu, 2014).

Sentetik çevre ise insanı doğadan koparırken, doğal yeteneklerini kaybetmesine neden olmaktadır. $\mathrm{Bu}$ bağlamda, Winx çizgi film serisi perileri, gerçek dişı bir dünyada atanmış sihirli güçleri ile efsanevî yaratıklara, cadılara ve diğer düşmanlara karşı savaşmak durumundadir. Oysaki gerek Viking Vicky gerekse Heidi'nin karşılaştıkları sorunlar gerçektir ve bunlarla kıvrak zekâları, cesaretleri, kendine güvenleri ve insan sevgileri ile mücadele ederler. Gerektiğinde zor durumdaki kötülere dahi yardım eli uzatılırken, hiç kimse dışlanmamaktadır. Winx Club çizgi film serisinin kötü kahramanı Valtor ile iyi peri Bloom karakterinin ilk karşılaşmalarında aralarında geçen konuşmalar aydınlatıcıdır. Valtor, Bloom'a şöyle der: “Benim 
hakkımda bir sürü kötü şey duyduğuna eminim, ama unutma; insanların abartma huyu vardır." Valtor şöyle devam eder: "Benimki eski bir hikâye, bir zamanlar güçlü ve sayg1değer biriydim, ama herşey çok değişti." "Bana ait olanı almak üzere tekrar geri döndüm." "Sihirli boyutun en güçlü kurucusu olmak istiyorum." "Ac1 ve y1k1m istemiyorum, yoluma çıkmaz ve benimle birlikte olursan hakettiğini alırsın." "Sadece bana ait olanı istiyorum." Ancak gerek Heidi gerekse Viking Vicky filmindeki kötü kahramanlar, Valtor gibi ölesiye hırs dolu ve güç delisi değildir. Aynı şekilde Arı Maya çizgi filminde de ufak tefek kıskançlıklar ve yanlış anlamalar nedeniyle oluşan ve iyi niyetle düzeltilebilen sorunlar vardir. Vicky çizgi filmşideki kötü korsan Swan bile gerek konuşması gerekse komik hâlleri ile insanı güldürür. Kısaca, sonsuz güç isteyen, herşeyin kendine ait olduğunu düşünen, kendini Tanrı yerine koyan bir kötü karakter, Heidi, Viking Vicky ve Arı Maya'da yoktur. Diğer yandan, tüm teknolojik aletleri kullanabilen; makyajı, tırnağı, abartılı giysisi bozulmasın diye hassasiyet gösteren; yemek, temizlik, gibi işlerden hoşlanmayan ve bencil davranışlar gösteren Winx perileri, yerel kültür öğelerinin dışında, sentetik bir çevrede yaşayan estetikli mankenler gibidir ve iyilik yaparken bile tüketimi özendirirler (WinxClubEnglish, 2018).

Öte yandan, Tek Boynuqlu Atrn Sirn isimli bölümünde geçen konuşma, Amerikan yaşam tarzını ve kişisel öyküleri paylaşan ve Türkçe bir televizyon kanalı olan TLC'nin Kupon Biriktiricileri belgeselindeki indirimli alışverişi tasarruf sanan ve evlerini çok fazla eşya ile istifleyen bağımlıların görüşleri ile birebir aynıdır. Örneğin:

Stella: "İnanamiyorum! İndirimde olan her şeyde indirim yapıyorlar. Bu ne demek biliyor musun?"

Bloom: "Hızlı alışveriş turumuz, sonsuz bir yolculuğa dönüşüyor mu demek?”

Stella: "Hayır. Ne kadar çok alırsak o kadar çok tasarruf ediyoruz demek!’. (Winx Club Türkiye, 2016)

Tek Boynuə̨lu Atın Sırn isimli bölümde karşımıza başka bir tezatlık da çıkmaktadır. Zira Winx perileri, kötülük sihri yapılan tek boynuzlu at tarafindan ölümle tehdit edilen yavru pandaları kurtarmak üzere mücadele ederler. Bir tarafta yaşadığı doğayı ve hayatı korumak üzere seferber olmuş periler, diğer tarafta ne kadar satın alırsak o kadar tasarruf ederiz şeklindeki slogan ile alışveriş tutkunu gösterişli periler... Esasen, gerçek hayatta kötü sihirle kötüleşen tek boynuzlu at değildir. Aşırı üretim ve tüketime bağlı çevresel kirlenme, pandaların hayatını tehdit etmektedir (Winx Club Türkiye, 2016).

\section{Lüks tüketim öznesi ve teşviki olarak Winx çizgi filmi}

Tüketici belleğinde oluşturulmak istenen bir düşünce, gerek çizgi filmler, reklamlar ve gerekse sanal ortamdaki oyunlar ile kazınmaktadır. Zihinsel olarak çocuğun algisında konumlandırılan bir ürün, önünde sonunda en az bir kere satın alınmaktadır (Uğur, 2018). Bilhassa çizgi film karakterlerinin resimlerinin, kıyafetlerin, kırtasiye malzemelerinin, yiyecek ve içecek malzemelerinin üzerinde yer alması uyarıcı bir etki yaratmaktadır. Günümüzde birçok aile çocuklarının televizyon başında saatlerini geçirmesine müsaade etmektedir. Bevillard'a göre televizyon sanki bir elektronik biberon gibi kendine ait kodları, kuralları ve tüketim kültürünü empoze ederek çocuğun düşünce dünyasını çok kolay bir biçimde şekillendirmektedir (Yağlı, 2013).

Popüler kültür ya da tüketim kültürü, stres, aşır1 rekabet gibi sıkışmışlık hissine karşı insanları televizyon dizileri, filmler, reklamlar ve bilgisayar oyunları ile eğlence dünyasının içine çekmektedir. Böylelikle hayata, düzene, eşitsizliğe karşı yapılan sorgulama ve düşünme yeteneğinin azalmasıyla suni bir tüketim mekanizmasının verdiği mutlulukla, fiziksel olarak pasif, zihinsel olarak sürekli meşgul bırakılırız. Türkiye'de TÜİK tarafindan yapılan Zaman Kullanım Araştırması (2014-2015) verilerine göre çalışma dışında ki boş zamanlarımızda televizyon izleme oranımız \%94 (günlük yaklaşı 330 dakika) oranında gerçekleşmektedir (TÜİK, 2016). Çizgi filmler, hem okul öncesi hem de okul dönemi çocuklara ve gençlere yönelik kurguları içinde barındırır. Görsel efekler, hayali kahramanlar, maceralar ile süslenen çizgi filmler, çocuklar için bu büyülü dünyada olayların, varlıkların ya da kurgunun gerçek olup olmamasını önemsizleştirir (Akpınar, 2015). Winx perilerinin şık ve pırıltı giysileri, aksesuarları, makyajları, bakımlı ve renkli uzun saçları, ojeli uzun tırnakları, topuklu ayakkabıları ve her koşulda bakıml görünümleri, çocukları ve geçleri görsel ve zihinsel olarak etkilemektedir. Nitekim Winx perileri, arkadaşlık, dayanışma gibi duyguları harekete geçirirken, diğer taraftan kendinden olmayan sihirli güç, sözde güzellik algisını yerleştirirken (Nickelodeon ile ortaklık öncesi daha sportif giyim tarzını tercih eden periler, bu ortaklıktan sonra, daha şatafatlı ve klasik giyim tarzına yönelmiştir) sadelikten uzaklaştırmakta ve tüketimi özendirmektedir. Zira, gerek buzlar kraliçesi Elsa ve kardeşi Anna gerekse Winx perileri, çocuk ve genç ayakkabıları, giysileri, nevresim takımları, süs eşyalar1, kırtasiye malzemeleri vb. üzerine basılmakta ve bu yolla satışlar artırılmaktadır.

Winx Club Beklenmedik Bir Olay, oldukça ilginç bir 
başlangıç bölümüdür. Orta hâlli bir anne babanın kızı olan Bloom'un kendine ait odası ve bahçeli bir evleri vardır. Bir cumartesi sabahı annesi onu erken kaldırdığ1 için kızmaktadır. Okuduğu kitap için annesinin "Periler efsane mi, gerçek mi? Çok aptalca şeyler bunlar!" eleştirisine "Efsaneler ve periler aptalca değiller!" șeklinde kızarak karșılık verir. Aşağıya indiğinde babasına, "Tatil günümü dükkânda geçirecek değilim, arkadaşlarımla eğlenceli bir yere gitsem?” der. Babasının "Büyüdüğünde dilediğin yere gidebilirsin." sözüne karş1lık Bloom ise ses tonunu yükselterek "Ne zaman büyümüş olacağım? 16 yaşımdayım ya!” der. Babasının "Birkaç hafta içinde her yıl yaptığımız gibi sahile gideceğiz." sözüne karşılık "Bütün arkadaşlarım tatile yalnız çıkıyor, bu mükemmel sürpriz olabilir!” şeklinde karş1l1k verir. Annesi de, "Hediye demişken sana bir süprizimiz var." der ve bahçedeki bisikleti gösterir. Bloom memnuniyetsiz şekilde teşekkür ederken, babası "Gördün mü? Dili tutuldu." der; annesi ise "Emin değilim. Belki daha sofistike bir şey bekliyordu." der ve ekler: "Mesela bir motosiklet." Babas1 "Onların parasından haberin var mi?" derken, annesi "Para biriktirelim, belki önümüzdeki sene bir tane alabiliriz". der. Karşılaştığı kız arkadaşı “Tatili Gardenya'da m1 geçireceksin Bloom?" derken Bloom "Yakında annem ve babamla bir yerlere gideceğiz." der. Kız arkadaş1 "Sana gittiğim yerden kart atarım, hiç olmazsa farklı bir yerler görürsün.” derken nakliye aracindan indirilen motosikletine bakarak ekler: "Dikkatli olun! Daha yeni aldık, en yeni model." der. Bloom sinirle uzaklaşırken "Nasıl da hava attı!" demektedir (Winx Club Türkiye, 2015b).

Daphne Kim? isimli bölümde yine tüketim ve gösteriş kültürüne yönelik konuşmalar vardır. Bunlar arasında odasından Stella'nın odasına gelen Flora için Stella, "Bu sensin Flora. Bu parfümü her yerden tanırım." demektedir. Bir başka diyalogda Stella Bloom'a "Bu arada saçına ne yaptın sen? Yumurta çırpıcısıyla mı fırçaladın?” diyerek saç bakımını hatırlatır (Winx Club Türkiye, 2015c).

Türkiye'de Panini Medya Yayıncıllk ve Ticaret A.Ş. tarafindan çıkarılan Winx Club dergisi, Winx Fairytale Tek Kişilik Nevresim takımı reklamları, moda ve stil önerileri, makyaj yapımı, aksesuarlar, giysiler, fotoğraf çekiminde daha iyi poz vermenin tüyoları gibi pek çok konuda öneriler sunmaktadır. Her sayıda bir sihirli test vardır. 2018-159 numaralı sayısındaki sihirli teste, çoktan seçmeli sorular içerisinde $C$ şıkkını en çok işaretleyenlerin Stella'ya benzediğini söylemektedir. C seçeneğine bir göz atarsak, alışveriş yapmak, moda tasarımcısı, güneş gözlükleri, deniz kenarına gitmek gibi cevaplar, günümüz lüks tüketim kültürünün sembolü olan Stella karakteri hakkında zihin altı imgelerdir. Her sayıda resimli Winx çizgi romanı yer alır. Bilhassa çizgi romanlarda bazı faydalı telkinler olmakla birlikte (örneğin Buzlar Adası: Kardeşlik ve destek olmak; Konser Zamanı: Doğruyu söylemek ve hakkını vermek; Yeteneğini Keşfetmek: Anlaması kolay olmasa da herkesin diğerlerinden farklı ve özellikli bir yeteneği vardır...) şatafatlı resimler, alışveriş, giyim, makyaj, poz verme, iyi yaşam ve lüks hayat önerileri ise daha yoğundur (Winx Club Dergileri, Panini Medya, 2018).

Lüks yaşam ve partiler, çizgi filmin bölümlerinde s1klıkla yinelenmektedir. Valtor’un Issareti bölümünde Winx Club kızları sohbet etmektedir. Hepsi Laila'nın nerede olduğunu merak etmektedirler. Stella "Laila yüzyılın partisini kaçırmayacaktır." der. Bloom ise "Ama benim doğum günüm Aralık'ta. Ah! Kendi partinden bahsediyorsun." şeklinde cevap verir. Stella sinirlenerek "Tabii ki tatlım, prenses balosu yarın." şeklinde cevap verirken Bloom gülmektedir. Stella şaka yaptıklarını anlar (Winx Club Türkiye, 2013).

Her bölümde farklı ve daha gösterişli kıyafetler giyen Winx perileri zaman ilerledikçe, daha abartılı giyinmeye başlamıştır. Nitekim eğlence dünyası ünlüleri de çizgi filmlerden çok etkilenmektedirler. Keza dünyadaki en genç zenginler listesinde başlarda yer alan Kylie Jenner, kızının ismini bu çizgi filmdeki Trix cadıları arasından Stormy ismini çağrıştıran Stormi koymuştur. Kızı Stormi için yaptığ1 doğum günü partisi ile uzunca bir süre gündemden düşmeyen Kylie'nin seçtiği mekân troller, karlar kraliçesi gibi temaları içeren bir abartılı gösteri içinde aşırı şaşalıdır ve sanki büyülü bir evrendir. Benzer şekilde bizim ünlülerimizden Ali Şan, bir yaşına giren oğlunun doğum günü partisi için Mickey Mouse başta olmak üzere pek çok Walt Disney kahramanlarını içeren bir konsept ile langırt, kaydırak, boğa güreşi gibi çeşitli aktiviteleri yerleştirtmiştir. Demet Akalın tarafindan verilen hediyenin basına yansıdığı partide Akalın, "Alişan, Kylie Jenner'ın kızı Stormi'nin partisini gölgede bırakmış. Benim seneye bunu geçmem lazım." şeklinde yorum yapmıştır (Kylie Jenner'dan kızı Stormi'ye, 2020; Alişan'ın oğlunun doğum günü, 2020).

\section{Sonuç}

Kitle iletişim teknolojisi sayesinde en yaygın kitle iletişim araçlarından televizyon ve sanal iletişim (internet) aracıllğg ile yayımlanan Winx çizgi animasyon serisi, Türkiye'de büyük bir topluluğa ulaşabilmektedir. Winx çizgi filmi serisinin başlarında periler daha sportif, sade ve az makyajlı bir görünüm sergilerken, bilhassa Nickelodeon ortaklığı sonrası daha gösterişli, makyajlı ve sürekli kıyafet değiştiren bir durumdadır; hattâ erkek kahramanların dahi saçları yapilı ve boyalıdır. Her duruma ve mekâna göre elbise, aksesuar, saç modeli değiştiren periler, gerek kötülükle savaşırken gerekse ormanda yürüyüş yaparken dahi topuklu ayakkabıları, makyajlı yüzleri ve uzun saç ve tırnakları ile dikkat 
çekicidir. Güncel teknolojik aletlerin kullanıldığı, her türlü tüketim öğesinin yerleştirildiği çizgi filmde, bir taraftan ebeveynlere yönelik olarak Okyanusun Gizemi bölümüdeki gibi okyanusları kirlilikten kurtarmak üzere ya da Tek Boynu§lu Atm Sirn bölümünde olduğu gibi pandaları kurtarmak üzere hareket geçen periler, kötü sihri iyi sihirle düzeltirler. Ancak tüm bunları yaparken, podyumda yürüyen mankenler gibi süslü ve gösterişlidirler. Oysaki kötü sihirle değil, bu denli aşırı üretim ve tüketimin gerçekleştiği dünyada, okyanuslar hızla kirlenmektedir. 75. Yıllık Birleşmiş Milletler Toplantısı'nda konuşan dönemin ABD Başkanı Trump, Çin'i dünyanın kimyasal atık merkezi olarak tanımlarken okyanusları plastik atıklarla kirletmekle suçlamaktadır (US President addresses general debate, 2020). Küresel ısınma nedeniyle gelecek yıllarda Eylül ayının Ağustos ay1 gibi sıcak olacağ1 (Eylül ayı, 2020), şu anda var olan bazı bitki ve hayvan türlerinin hızla yokolduğu ve diğerlerinin tehlikede olduğu, İznik Gölü'ndeki çekilme nedeniyle suyun içinde tarihsel kalıntıların ortaya çıtı̆ı̆1 (Göl çekildi, 2020), Avustralya açıklarında yaklaşık 400 tane balinanın öldüğü (Avustralya'da kıyıya vurup, 2020) haberleri ise günden güne çoğalmaktadır. Tüm bu yaşananların nedeni ise aşırı tüketim ve aşırı üretimde aranmazken, bilakis COVID-19 nedeniyle izolasyon ve evde kalma döneminde şirketlerin reklam harcamalarının ve gelirlerinin arttığını görmekteyiz (Avrupa'da dijital reklam, 2021).

Diğer taraftan tüketime dayalı yayınlar hız kesmeden artarken, toplumsal gerçeklikten uzak Winx Club çizgi film serisi ürünlerinin satışları pek çok ülkede yaygındır. Heidi çizgi filminin kış ayında geçen bir bölümünde Heidi'nin büyük babası, külübeden kasabaya giden yolu kardan küremiştir. İş bitince Heidi ve büyükbabası kulübenin önünde otururlar ve büyükbaba şunu söyler: "Ancak gerçekten çalışan kişi, dinlenmenin tadına varır." (Exxen Çocuk, 2021).

TLC'nin Ağır Yasamlar isimli yayını obez insanların zayıflamak için verdikleri mücadeleyi anlatmaktadır. 38 yaşındaki erkek hasta ile doktoru arasındaki konuşma bir hayli ilginçtir (TLC, t.y.). Doktorun "Bu kiloyla fazla yaşamayacağını biliyorsun, değil mi?” diye sorduğu hastası "Bu yaşıma kadar gelebildiğime şaşırıyorum." diyerek cevap verir. Doktor ise "Bir sihirli değneğin yaşamını aniden değiştirmesini ve herşeyin düzelmesini mi bekledin o zaman?” şeklinde cevap vererek, günümüz toplumunun doğadan kopuşunu anlatmaktadır.

Winx serisi, dışardan atanmış sihirli güçlerle düşmanlarına karşı mücadele eden perileri anlatır. Bu periler, aklın, cesaretin, umudun, sabrin ve kendi gücüyle mücadelenin temsilcileri değildirler, aksine prriltılı yaşamları aşırı gösterişli giyim tarzları ile herşeye üsten bakarlar ve herşeyin çözümünü sihirde ararlar. Winx perileri fit görünüşleri, sağlıklı dalgalı uzun saçları ve
Asya ile Avrupa motiflerini birleştiren yüzleri ile fiziksel görünüşü ön plana çıkarırlar. Dış görünüşün ve şatafatın her türlü kapıyı açacağını îmâ ederler. Popülerlik dış görünüşten gelmektedir. Bu nedenle çocuklar ve gençler üzerinde tek tip güzellik ve gösteriş ile popüler olma algisını yerleştirmektedir.

Nitekim Arkadaşlar Ne Ị̇indir? bölümünde Bulutlu Kule'ye izinsiz girdikleri için cezalandırılan Winx perilerinin okullarında sihir kullanmadan temizlik yaparlarken, aralarında ilginç bir konuşma geçer. Periler süpürge ve firçaların nasıl kullanılması gerektiğini bilmemektedir. Ancak içlerinden Stella hiç yardım etmemektedir. Perilerden biri "İsmi lâzım değil yardım etseydi çoktan bitirmiştik!" der. Bloom "Yer temizliği konusunda anlaşmıştık." der. Stella ise tırnaklarını törpülemektedir ve cevap verir: "Tirnaklarım mı kırılsın?" Diğer peri "Eldiven giy." derken Stella "Kauçuk ellerime dokunuyor." diye karşl11k verir. Temizlik bittikten sonra bütün Alfea'nın katılacağı bir konser bulunmaktadır; ancak temizliğin bitmemesi üzerine periler, Uzmanlar isimli sevgililerini yardıma çağırır (Winx Club Türkiye, 2012). Winx perilerinin bu davranışı geleneksel cinsiyet profilinden uzak, eşitlikçi bir yaklaşım sağlamakla beraber aynı zamanda çalışmak ve sorumluluklarımızı yerine getirmeye ilişkin ahlâkî değerlerin çok ötesinde, özgürlügün giyim kuşam ve görüntüde olduğu şeklinde bir algıyı da empoze etmektedir. Nitekim ünlü İngiliz futbolcu David Beckham'ın büyük oğlu Brookly Beckham'ın ojeli tırnaklarının çeşitli gazete ve kanalları süslemesi (Brooklyn Beckham'ın ojeli tırnakları, 2020) erkeklerde ojeli tırnak modasının başlangıcını yapan Christiano Ronaldo'nun fotoğrafları (Christiano Ronaldo'nun ojeli tırnakları, 2016), erkek modasının değişen çizgisi ile Paris, Londra ve Milano'daki moda haftalarından yapılan yayınlar ve görseller, farklılaşmış bir diş görünüşe artan ilginin kanıtlarıdır. Gazete, dergi, televizyon ve diğer tüm kitle iletişim araçlan ile günümüzde zenginlik, lüks tüketim ve gösteriş daha önce hiç olmadı̆̆ kadar yüceltilmektedir. Tüketim toplumunu farklı bir görsellikte ve tüketim değerleri imgeleri ile yansıtan Winx Club animasyonu bu açıdan çok önemlidir. Başka hangi çizgi filme "Haydin kızlar indirim var! Tüketerek tasarruf edelim." mesajı bu kadar yakışabilir?

\section{Kaynakça}

Abelsson, A., ve Willman, A. (2020). Ethics and aesthetics in injection treatments with botox and filler. Journal of Women \& Aging. https://doi.org/10.1080/08952841.2020.1730682

Addison, H. (2006). "Must the players keep young?": Early Hollywood's cult of youth. Cinema Journal, 45(4), 3-25. https:// doi.org/10.1353/cj.2006.0037

Akagün, E. (2019, Ocak 1). 3 çocuk annesi Megan Fox'un seksi vücudunun sirlar1. Muscle \& Fitness. https://muscleandfitness. 
com.tr/uc-cocuk-annesi-megan-fox-ve-seksi-vucut-sirlari/

Akpinar, T. (2015). Popüler kültür içerisinde çocuklarn tüketime yönlendirilme süreçleri [Yayımlanmamış yüksek lisans tezi]. Marmara Üniversitesi, Sosyal Bilimler Enstitüsü, İstanbul.

Alatlı, A. (2014). Bati'ya yön veren metinler, Cilt 1, 2 ve 3. Alfa Yayıncilik.

Alişan'ın oğlunun doğum gününe Demet Akalın'ın hediyesi damga vurdu. (2020, Şubat 17). Yeniçağ Gazetesi. https://www. yenicaggazetesi.com.tr/alisanin-oglunun-dogum-gununedemet-akalinin-hediyesi-damga-vurdu-268453h.htm

Avrupa'da dijital reklam yatırımları en fazla büyüyen ülke Türkiye oldu. (2021, Haziran 7). HaberTürk. https://www.haberturk. $\mathrm{com} /$ dijital-reklam-yatirimlarinda-turkiye-avrupa-da-zirveyecikti-haberler-3096639-teknoloji

Avustralya'da kıyıa vurup ölen balinaların sayısı 380'e yükseldi. (2020, Eylül 21). BBC News Türkçe. https://www.bbc.com/ turkce/haberler-dunya-54264660

Ayakkabı alabilmek için internette bir haftalık bebeğini satışa çıard1. (2020, Ekim 11). TV100. https://www.tv100.com/ rusyada-25-yasindaki-luiza-gadzhieva-isimli-anne-kendineayakkabi-alabilmek-icin-internette-bir-haftalik-bebeginisatisa-cikartti-video-518328

Batu, M., ve Tos, O. (2017). Tüketim kültürü odağında modernizm ve postmodernizmin karşılaştırılması. Gümüshane Üniversitesi İletișim Fakültesi Elektronik Dergisi, 5(2), 991-1023. https://doi. org/10.19145/e-gifder.296888

Baudrillard, J. (1997). Tüketim toplumu. H. Deliceçaylı ve F. Keskin (Çev.). Ayrıntı Yayınları.

Bauman, Z. (1999). Calısma, tüketicilik ve yeni yoksullar. Ü. Öktem (Çev.). Gündüz Basın Yayım Dağıtım.

Bhattacharjee, P. (2017, Kasim 15). How does your child's screen time measure up? CNN Health. https://edition.cnn. $\mathrm{com} / 2017 / 11 / 15 /$ health/screen-time-averages-parenting/ index.html

Bosse, C. L. (2007). Becoming and consumption. Lexingston Books.

Brooklyn Beckham'ın ojeli tırnakları. (2020, Şubat 7). NTV. https://www.ntv.com.tr/galeri/yasam/spanbrooklynbeckhamin-ojeli-tirnaklari-span,pgvf bj3ukKSnCcusjc8yw/ TdXICoEYWUeN-DdL5--HOw

Bulut, M. (2005). Kadın, kültür ve depresyon. Antropoloji, (20), 37 45. https://doi.org/10.1501/antro_0000000219

Christiano Ronaldo'nun ojeli tırnakları. (2016, Ağustos 1). NTV. https://www.ntv.com.tr/galeri/yasam/ christiano-ronaldonun-ojeli-tirnaklari,wc9ET jbIEutDvtBrEwcrw/3sPTDZ0OHkG4T26taZJUxg

Çubukçuoğlu, H. F. (2017). Kurumsal kuram penceresinden halkla ilişkiler: Nestle ve palm yağ1 krizi. İletişim Kuram ve Araştırma Dergisi, 1(44), 173-192. https://iletisimdergisi.hacibavram. edu.tr/index.php/IKAD/article/view/335/331

Dedeoğlu, A. Ö, ve Savaşç1, İ. (2005). Tüketim kültüründe beden güzelliği ve yemek yeme arzuları: Kadınların tüketim pratiklerine yansıması. Ege Akademik Bakıs Dergisi, 5(1), 77-87. https://dergipark.org.tr/en/pub/eab/issue/39836/472332

Demirel, S. ve Yegen, C. (2015). Tüketim, postmodernizm ve kapitalizm örgüsü. Ankara Üniversitesi İlef Dergisi, 2(1), 115138. https://doi.org/10.24955/ilef.305275
Ertürk, K.Ö. (2009). Medyada kültürel değerlerin temsili ve sosyal sorumluluk: Evlilik yarışmaları ve programlarının etik açıdan değerlendirilmesi. M. Yağbasan (Ed.) içinde, Furat Üniversitesi, İletişim Fakültesi, Medya ve Etik Sempozyumu Bildiriler Kitabı (s. 137-146). Elazığ.

Esin, P. (1982). İsbölümü, yabancılaşma ve sosyal politika. Ankara Üniversitesi Siyasal Bilgiler Fakültesi Yayınları, No. 502. Ankara.

Exxen Çocuk. (2021, Mart 26). Heidi 8.bölüm Malikânede hapis TRT cocuk | Türkşe dublaj HD | [Video]. YouTube. https://www. youtube.com/watch? $\mathrm{v}=\mathrm{dJH}$-gftoY1c

Eylül ay1 artık Ağustos gibi olacak. (2020, Ekim 16). NTV. https://www.ntv.com.tr/turkiye/eylul-ayi-artik-agustos-gibiolacak,rLhXXgEw00qWPhuaSKQudQ

Foucault, M. (2005). Özne ve iktidar. I. Ergüden ve O. Akınhay (Çev.). Ayrıntı Yayınları.

Frisk, H., ve Yoshida, M. (2005). New communications technology in the context of interactive sound art: An empirical analysis. Organised Sound, 10(2), 121-127. https://doi.org/10.1017/ $\underline{\mathrm{S} 1355771805000762}$

Göl çekildi, 1500 y1llık bazilika ortaya çıktı. (2020, Ekim 16). Cumburiyet/IHA. https://www.cumhuriyet.com.tr/haber/ gol-cekildi-1500-yillik-bazilika-ortaya-cikti-1773906

Gürler, G. (2018). Estetik cerrahi müdahale görmüş bireyler üzerine bir alan araştırması. Sosyoloji Dergisi, (38), 141-172. https:// dergipark.org.tr/en/pub/sosder/issue/50034/641391

Güven, Ö. (2009). Yeni iletişim teknolojileri ve etik-2. M. Yağbasan (Ed.) içinde, Furat Üniversitesi, Illetişim Fakültesi, Medya ve Etik Sempozyumu Bildiriler Kitabı (s. 73-87). Elazı̆̆.

Güzel, E. (2013). Kültürel bağlamda kadın ve güzellike [Yayımlanmamış doktora tezi]. Yeditepe Üniversitesi, Sosyal Bilimler Enstitüsü, İstanbul.

Heller, H. (2011). The birth of capitalism: A 21st century perspective. Pluto Press. https://doi.org/10.2307/j.ctt183p671

Honigman, R., ve Castle, D. J. (2006). Aging and cosmetic enhancement. Clinical Interventions in Aging, 1(2), 115-119. https://doi.org/10.2147/ciia.2006.1.2.115

İşcanoğlu, K. (2014). Sentetik çevre, sanat ve algz ilişkisi: Günlük denemeleri [Yayımlanmamış yüksek lisans tezi]. Hacettepe Üniversitesi Güzel Sanatlar Enstitüsü, Ankara.

Jahn, O. (1867). Winckelmann [The history of ancient art among the Greeks kitap incelemesi, J. Winckelmann]. Westminster Review, 80-110. https://core.ac.uk/download/pdf/35123764.pdf

Jha,M.R. (2015). Theglobalbeantyindustry: Colorism, racism, and the national body. Routledge. https://doi.org/10.4324/9781315733432

Karaboğa, M. T. (2018). Medya çağında çocuk ve çocuk kültürü: Şiddet ve tüketim kültürünün yansımaları. Uluslararası Cocuk Edebiyatı ve Eğitim Arasttrmalar Dergisi (CEDAR), 2(2), 1-17. https://dergipark.org.tr/en/pub/chedar/ issue / 42042/478139

Kübra Boyraz'in botoksunu yapan kişi ilkokul mezunu çıktı. (2020, Eykük 28). Milliyet. https://www.milliyet.com.tr/galeri/ kubra-boyrazin-botoksunu-yapan-kisi-ilkokul-mezunucikti-6316122

Küçük, Ö. (2019). Liberal aydınlanmanın akıl, birey ve özgürlük 
üzerine düşüncesel yansıması olarak Heidi ve Vikingler çizgi filmleri örneği. Ö. Gökkaya, İ. Kilıcaslan, B. Demir ve K. Kahraman (Ed.) içinde, International Marmara Social Sciences Congress (Autumn) 2019 Social Sciences Proceedings E-Book (s. 300306). Kocaeli Üniversitesi. http://imascon.com/dosyalar/ imascon2019guz/imascon sosyal bildiriler guz 2019.pdf

Kylie Jenner'ın kızı Stormi için muhteşem doğum günü partisi. (2020, Şubat 3). Vogue. https://vogue.com.tr/haber/kyliejennerdan-kizi-stormiye-dogum-gunu-partisi

Neu, D., ve Gomez, E. O. (2006). The ethics of World Bank lending. Accounting Forum, 30(1), 1-19. https://doi.org/10.1016/j. accfor.2005.12.001

Nostalji Kasabası. (2017, Aralık 17). Vikingler - Türkçe Dublaj Bölüm 1 [Video]. YouTube. https://www.youtube.com/ watch? $=$ =JFLGC3 jvr4

Oral, S.B. (2014). Lükes tüketim algisı ve lüks tüketim odakl tüketici davramıslar üzerine bir araștırma [Yayımlanmamış doktora tezi]. Maltepe Üniversitesi, Sosyal Bilimler Enstitüsü, İstanbul.

Özer, Ö, ve Sinav, A. (2009). Etik ve sosyal sorumluluk. M. Yağbasan (Ed.) içinde, Furat Üniversitesi, İletişim Fakültesi, Medya ve Etik Sempozyumu Bildiriler Kitabı (s. 113-123). Elazığ.

Postman, N. (2004). Televizyon: Öldüren eğlence, 2. bask1. O. Akınhay (Çev.). Ayrıntı Yayınları.

Pösteki, N. (2019). Sinema yolu ile oluşturulan dünyalar: Yok-yer, Heterotopya ve Ömer Kavur sinemas1. SineFilozofi Dergisi, 7590. https://doi.org/10.31122/sinefilozofi.512542

Ritzer, G. (2011). Grobalization. G. Ritzer (Ed.) içinde, The Wiley Blackwell Encyclopedia of Globalization. Wiley- Blackwell. https://doi.org/10.1002/9780470670590.wbeog260

Slee, P. T. (2002). Child, adolescent and family development, 2nd edition. Cambridge University Press. https://doi.org/10.1017/ CBO9781139164948

Tarvainen, J., Westman, S., ve Oittinen, P. (2015). The way films feel: Aesthetic features and mood in film. Psychology of Aesthetics, Creativity, and the Arts, 9(3), 254-265. https://doi. org/10.1037/a0039432

TLC. (t.y.). Ağır yaşamlar, 8. sezon 14. bölüm [Video]. TLC. https:// www.tlctv.com.tr/agir-yasamlar/8-sezon-14-bolum

Tunç, M. (2017). Aydınlanmacı özne-birey projesine dair (tüketimsel açıdan) bir değerlendirme. Şarkiyat, 9(2), 532-544. https:// doi.org/10.26791/sarkiat.321752

Turkay GT. (2020, Şubat 17). Winx Club Kayıp Krallĭgn Sorr 1 Full 1080p Türkse Dublaj iæle [Video]. YouTube. https://www. youtube.com/watch? $\mathrm{v}=\mathrm{t} 6 \mathrm{~V} 6 \mathrm{tiTNPp0}$

TÜİK (2016). Zaman kullanm arastırmast mikero veri seti, 2014-2015 (No. 4426). https://www.tuik.gov.tr/media/microdata/pdf/ zaman-kullanimi-arastirmasi.pdf

Uğur, U. (2018). Marka: Kimlĭğ, imaji, değeri, farkindaliğr, güveni, bağhlı̆̆ı. Eğitim Yayınevi.

United States - President addresses general debate, 75th session (2020, September 22). [Video]. UN Web TV. http://webtv. un.org/watch/united-states-president-addresses-generaldebate-75th-session/6193440156001

Ünlülerin fitness eğitmeni Tammy Hembrow kazanciyla dudak uçuklatt1. (2019, Mart 5). Sabah Günaydrn. https://www.sabah. com.tr/magazin/2019/03/05/unlulerin-fitness-egitmeni- tammy-hembrow-kazanciyla-dudak-ucuklatti

von Schiller, J. C. F. (2017). Letters upon the aesthetic education of man. https://openspaceofdemocracy.files.wordpress. $\mathrm{com} / 2017 / 03 /$ letters-on-the-aesthetic-education-of-man. pdf

Wallman, J. (2018). İstif çağı. S. Karagözoğlu ve A. Özgören (Çev.). Doğan Egmont Yapımcılık ve Yayıncilık.

Wijethilaka, R. G. T. S (2020). Effect of cartoons on children. https://www.researchgate.net/publication/345066689

Winx Club (2018). Yepyeni bir macera: Konser zamanı. Sayı: 159, Panini Medya Yayıncılık ve Ticaret A.Ş.

Winx Club (2018). Yepyeni bir macera: Buzlar adası. Sayı: 160, Panini Medya Yayıncılık ve Ticaret A.Ş.

Winx Club (2018). Yepyeni bir macera: Yeteneğini keşfet. Say1: 161, Panini Medya Yayıncılık ve Ticaret A.Ş.

WinxClubEnglish. (2018, Haziran 16). Bloom VS Valtor [Video]. You'Tube. $\quad \underline{\text { https://www.youtube.com/ }}$ watch? $\mathrm{v}=\mathrm{iGb} 8 \mathrm{xeHpccY}$

Winx Club Türkiye (2012, Aralık 20). Winx Club - Sez̧on 1 Bölüm 7 - Arkadaşlar ne içindir? [Video]. YouTube. https://www. youtube.com/watch? $\mathrm{v}=\mathrm{pKSe} 9 \mathrm{NbpUy0}$

Winx Club Türkiye. (2013, Temmuz 1). Winx Club - Sezon 3 Bölüm 2 - Valtor'un İsareti - [TAM BÖLÜM] [Video]. YouTube. https://www.youtube.com/watch?v=k ctM9 PcJ4

Winx Club Türkiye. (2014, Eylül 24). Winx Club - Okyanusun Gizemi - Sarkisı ve Winx final dansı [Video]. YouTube. https://www. youtube.com/watch? $\mathrm{v}=2 \mathrm{c} 77 \mathrm{urMJzy} 8$

Winx Club Türkiye. (2015a, Kasim 30). Winx Club - Sezon 3 Bölüm 18 - Valtor'un Kutusu - [TAM BÖLÜM] [Video]. YouTube. https://www.youtube.com/watch?v $=$ wqYpeH84qW8

Winx Club Türkiye. (2015b, Temmuz 21). Winx Club - Sezon 1 Bölüm 1 - Beklenmedik bir olay [Video]. YouTube. https://www. youtube.com/watch? $\mathrm{v}=$ Ce tQrsholM

Winx Club Türkiye. (2015c, Temmuz 29). Winx Club - Sezon 1 Bölüm 9 - Daphne Kim? [Video]. YouTube. https://www.youtube. $\mathrm{com} /$ watch? $\mathrm{v}=\mathrm{xlcEZKPwaQw}$

Winx Club Türkiye. (2016, Aralık 10). Winx Club- 7. Sezon 13. Bölüm - Tek Boynuzlu Atın Sirn [TAM BÖLÜM] [Video]. YouTube. https://www.youtube.com/watch?v=Zt 5JuAw4Zg

Yağ aldırma ameliyatından 1 gün sonra öldü. (2018, Aralık 11). CNN Türk. https://www.cnnturk.com/turkiye/yag-aldirmaameliyatindan-1-gun-sonra-oldu

Yağlı, A. (2013). Çocuğun eğitiminde ve sosyal gelişiminde çizgi filmlerin rolü: Caillou ve Pepee örneği. Turkish Studies, 8(10), 707-719. https://doi.org/10.7827/TurkishStudies.5965

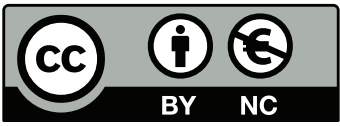

2021. Telif hakları yazar(lar)a aittir.

Bu makale Creative Commons Attf-GayriTicari 4.0 Uluslararası (CC BY-NC 4.0) lisansının hüküm ve şartları alında yayımlanan açık erişimli bir makaledir. 